\title{
1. Introduction: the attributes of the crisis
}

\author{
David Bailey, Dan Coffey and \\ Philip R. Tomlinson
}

\section{INTRODUCTION}

The collapse of the so-called 'bubble economy' in Japan in the first part of the 1990s saw a sharp drop in the rate of annual GDP growth between 1991 and 1992 followed by several years of stagnation, several years of recovery, and then a precipitous dip into recession - 'the worst since the Great Depression' (Gilpin, 2000: 278) - between 1997 and 1998; this was followed by a further period of stagnation marked alternately by hopes of an imminent and definitive revival and the fear of calamity. At the time of writing the Bank of Japan has just raised interest rates from a floor value of zero, based on a historically modest period of expansion in the national economy and the mildest of inflationary price rises. Whether this turns out to signal a definitive break from a difficult period as measured against main macroeconomic indicators, or another false dawn, remains to be seen. But however events subsequently unfold, Western perceptions of the efficacy of the Japanese economic machine have been indelibly marked: if the extent of Japanese exceptionalism and the causal forces supporting the Japanese 'economic miracle' was a hot topic for debate in the 1980s, by the close of the century - and notwithstanding the momentous and undisputable achievements of Japan in the field of economic development - debate had swung heavily to consider instead the extent of the Japanese malaise and the institutional factors sustaining it: 'Japanese, American and other experts', in the words of one eminent Western commentator on international affairs, now saw 'dire economic problems', and the need not only to take measures to stimulate the economy but also to institute wholesale economic reforms (ibid.: 279-82).

This book contributes to the ongoing debate by bringing together a series of contributions which consider the Japanese economic malaise and its impact on perceptions of Japan as an economic role model for others to emulate from a variety of perspectives, while pushing to the foreground of 
debate some issues that have perhaps hitherto lurked in the background. As befits its subject matter the contributors in question include leading economists and political scientists working in Japan, North America and Europe, providing a set of contributions that are both interdisciplinary in scope and international in origin, offering both new reflections and original research findings.

\section{THE ATTRIBUTES OF THE CRISIS}

It is possible to think of Japan as having undergone a crisis in a twofold sense. First, we might consider the crisis in the Japanese economy as such: which essential issues arise from the fact of a prolonged period of recession and threat of recession with respect to our understanding of Japan's economy and economic institutions? In this regard the book commences with commentaries which offer different perspectives on this problem. These consider in turn how the behaviour of economic actors and institutions in Japan might be informed by culturally embedded and specific features which vitiate the simple application of an orthodox Western (Walrasian) economic model to the analysis of the Japanese case; how an empirically led appraisal of the role of money and banking in the Japanese economy might explain both the asset price inflation of the 1980s and the subsequent long period of underperformance in the 1990s and beyond characterized by a persistent shortfall between actual and potential national output; and the power of giant corporations in Japan to pursue strategies which fail from a societal viewpoint. Second, we might consider too how, as the difficulties of Japan have unfolded, the status and respect accorded Japan as a world economic role model has declined. In this regard the book addresses not only the immediate question of Japan's economic travails at the level of the way the Japanese economy actually works and what policy inferences follow, but also the longer-term issue of Japan's status and reputation as a model for emulation.

One broad set of issues that is often overlooked is the particular crisis faced by Japanese industry and the problem of 'hollowing out' experienced by Japan's industrial base since the early 1990s, and the middle-section of the book is devoted to questions of state policy towards Japanese industry, and the impact of globalization on Japan's national economy. Issues here include the manifestation of the crisis in Japan's industrial regions and clusters, the future role of government regulation and the architecture of reform. These issues are again relevant not only to a complete understanding of important structural aspects of the crisis and attendant policy responses but also to the severe jolt taken in a wider international arena to 
the repute of Japanese economic organization. Arrangements in the industrial sphere have long been prominent in what today is often referred to in pithy terms as the 'competitiveness debate' - witness, for example, the interest shown by non-Japanese commentators in Japan's famous keiretsu networks, or the extensive debate on the attributes of Japanese firms as a 'source of competitive strength' (subtitle of a suitably illustrative volume compiled on this subject by Aoki and Dore (1994)). Again, the Japanese crisis is a twofold crisis, both aspects of which are explored in this book.

The studies in this book therefore comprise perspectives on (a) Japan's economic and industrial crisis, (b) the role of globalization in the crisis, (c) Japanese state industrial policy and industrial prospects, and (d) the status of Japan as a role model. The divisions must not of course be drawn too hard or fast. To understand the economic and industrial crisis of Japan is to ask overlapping questions. Issues relevant to the economic and industrial crisis in Japan - whether the explanation lies in the particular form of culturally induced responses to economic stimuli, the policies of Japanese banks and governing bodies, or the conduct of giant Japanese corporations in the context of globalization - are clearly relevant to what lessons are to be learned from Japan as a model of economic and industrial development. Reflection on the 'standard' or 'classical' model of the Japanese economy in the post-World War II era, on the role of administrative guidance and of an orchestrated state 'catch-up' policy, on social solidarity and on the impact of globalization and the opening up of the Japanese economy, is just as obviously relevant to the debate on international competitiveness.

The contributors to this book are almost by necessity drawn from a range of academic disciplines: in this book the reader will find essays written not only by economists but also by political scientists and specialists in international economic relations. Moreover, and as befits the keen international interest both in the historically impressive successes of Japan on the world stage in modern times and its current uncertainties, the contributions are multinational as well as interdisciplinary.

\section{CHAPTER CONTENTS AND PROGRESSION}

The individual chapters comprising this book, subject of course to our warning against overly simple lines of demarcation, divide broadly into three categories with respect to their place within the thematic structure of the collection as a whole. The development of themes and issues is best understood via a brief overview of content.

Chapter 2, by Donald W. Katzner ('The workings of the Japanese economy') considers the problems posed by Japan's recent travails from the 
viewpoint of what is non-applicable in the dominant Western model of market capitalism. The economic concerns of participating economic agents are culturally specific: whereas the vision of Western capitalism enshrined in the perfectly competitive (Walrasian) ideal posits self-interest as a motivating principle for economic actors, in Japan individuals are better described as valuing their personal contributions to the economy and society above incomes received. To understand a Japanese economy in terms that reflect Japanese cultural norms and values and hence the motives and concerns of Japanese citizens would imply a model written from a Japanese perspective: imported Western economic models are in this regard both superficial and ill-adapted to Japanese circumstances. Katzner explains why the culturally specific assumptions informing the perfectly competitive ideal of Western economics are vitiated in the Japanese case. The chapter explores in this context the particular content of Japanese institutional arrangements with respect to the industrial structure, the labour market, the distribution system and the role of the state; and it sets out the reasons why Western notions of efficient resource allocation are inappropriate in the Japanese case and policy recommendations good for the US (say) may be dangerous for Japan.

Chapter 3, by Richard A. Werner ('The cause of Japan's recession and the lessons for the world') sets out a careful review of the macroeconomic performance of Japan over the past 20 or so years combined with an original analysis of the causes of the long period of economic underperformance that set in with the 1991/1992 recession. The approach of structural reformers to Japan's economic malaise, which sees supply-side measures like deregulation, liberalization and privatization as being crucial to sustained macroeconomic recovery, is rejected on grounds of both empirics and theory. In this latter regard, Werner criticizes the structural reformers for confusing constraints on the potential output of an economy (on the supply side) with problems on the demand side which cause actual output to fall short of potential. After rehearsing the abundant evidence that the 1990s saw a declining trend in the utilization of productive capabilities, the chapter progresses to consider monetary explanations of the crisis: following a careful review of the main approaches taken by monetary economists to the failure of successive reductions in interest rates (both short- and long-run) to stimulate the Japanese domestic economy, supported by an assessment of the evidence for and against, Werner sets out the terms of an innovative analysis rooted in his own distinctive contributions towards an alternative approach to money and transactions. Identifying the creation of bank credit as the relevant constraint on the Japanese economy, the chapter concludes with an assessment of which policy measures could have been effective, 
political factors weighing against their adoption, and short- and long-term prospects for Japan.

Chapter 4, by Keith Cowling and Philip R. Tomlinson ('Transnational monopoly capitalism, the J-mode firm and industrial 'hollowing out' in Japan') adopts a stance towards the Japanese economic crisis of the 1990s based on the monopoly features of industrial capitalism. They argue that the root cause of these problems lies in the concentration of economic power in the upper echelons of corporate Japan and the subsequent globalizing activities of the country's large transnational firms. Cowling and Tomlinson argue that these firms have pursued their own global strategic interests, often at the expense of other stakeholders in Japan such as small firms and workers: the subsequent 'hollowing out' of Japan's industrial base represents in this sense a particular kind of strategic failure, in which corporate interests diverge from wider public interests. This analysis is developed first via an assessment of the characteristics of the Japanese firm, and a critique of the Aoki 'J-mode' model which seeks to establish these firms as being significantly different entities from their Western counterparts. After considering how economic power was concentrated within corporate Japan as a by-product of Japanese post-World War II industrial policy, Cowling and Tomlinson then explore the empirical realities of the consequences of corporate control of the Japanese economy for small firms, workers and Japan's industrial regions and macro economy.

These opening chapters set out some major themes. There are obvious differences of emphasis: the importance of culture as well as economy for Katzner; the workings of the Japanese monetary economy for Werner; the almost dialectical development of the Japanese corporation working first in accordance with and then against the wider interests of Japanese economic development. The next chapters explore transformations.

Chapter 5, by Ulrike Schaede ('Globalization and the Japanese subcontractor system'), considers the challenges of globalization to Japan's subcontractor system and the Japanese keiretsu. Using recent data, Schaede charts the movement in the 1990s of Japan's larger industrial suppliers in following their main contractors to produce overseas, a movement coinciding with new global cost pressures in manufacture which have had a significant impact upon Japan's domestic subcontractor system: the consequences of this for smaller Japanese subcontractors, and the notable decline in the membership of Japan's keiretsu networks along with the dismemberment of many cooperative supplier groups that have long been a distinctive feature of Japan's industrial structure, are explored. Carefully acknowledging that these changes may have both a positive and a negative impact upon Japan's domestic industry, Schaede considers the emergence of a new subcontracting system in which Japanese corporations look 
towards the global outsourcing of supplies involving fewer but larger suppliers and with supply-chain relations managed on an 'arm's length' basis, and with a greater emphasis upon competitive bidding than has been experienced in the traditional keiretsu model. The chapter concludes with an assessment of the requirements for survival, both of Japanese suppliers and for Japanese industries, in the new global environment.

Chapter 6, by Terutomo Ozawa ('Institutionally driven growth and stagnation - and struggle for reform') broaches the Japanese experience from the perspective of the interactions between the inner matrix of domestic institutional set-ups and the outer matrix of evolving global institutions and norms. Ozawa considers the past workings of Japan's dirigiste catchup regime, how institutional obsolescence set in, and how its economy has struggled to renovate its domestic set of institutions and practices: the bold thesis advanced is that the 'Japanese disease' (perceived to be a case of severe institutional sclerosis) is a necessary and cathartic event for Japan if it is to escape the trap of institutional obsolescence which has been the inevitable cost attached to the way in which Japan's economic catch-up strategy was organized and executed. In an analysis rooted in a rich understanding of geopolitical contexts in which a diminished American tolerance for Japanese catch-up after the end of the Cold War combined with Japanese economic success to drastically alter Japan's global and political economic environs, the chapter considers how Japan's part-aversion to foreign investment in Japanese industry is paradoxically morphing into an 'eagerness' to seek help from foreign firms. Ozawa asks whether the victory of Prime Minister Junichiro Koizumu signals that Japan is approaching a likely tipping point for critical institutional alteration.

Chapter 7, by David Bailey and Roger Sugden ('Küdōka, restructuring and possibilities for industrial policy in Japan') looks to the causes and extent of Japan's ' $k \bar{u} d \bar{o} k a$ ' - the process of hollowing out or deindustrialization - during the 1990s and early 2000s. The transformations under consideration here are twofold, encompassing both underlying structural reasons for this process and steps needed to redress these structural problems at the level of policy. In explaining Japan's küdōka, Bailey and Sugden find much of relevance in a 'government failure' approach, whereby the export success of certain sectors combined with import protection in others to produce a trade imbalance, continual yen appreciation and a rising cost base, spurring outward foreign direct investment by Japanese firms and a hollowing out of Japan's domestic industrial base. However, they argue that this analysis is an incomplete one unless due consideration is also given to the central role of Japanese transnational corporations in driving the hollowing out process, as a necessary link in understanding exactly how and why Japanese government policy failed. A policy frame- 
work to counter the attendant strategic failure is set out involving a mix of careful deregulation alongside a 'new' industrial policy that addresses economic governance issues, aimed at diffusing strategic decision making in the Japanese economy and at reinvigorating Japan's declining clusters of small firms.

Chapter 8, by Hiroyuki Odagiri ('The national innovation system: a key to Japan's future growth') considers the relationships between Japan's national innovation system and the changing nature of business within the country. Following a review of the evolution of innovation in Japan since 1945, and the shifting policy emphasis from imported technology in the post-World War II 'catch up' period to the home-grown science-based innovation of more recent decades, Odagiri discusses the importance of the changing research and development (R\&D) boundaries of the firm for future business competitiveness. Drawing upon recent specific examples from Japan's biotechnology sector, the case is made for firms to rethink boundaries and to consider greater interorganizational collaborations in R\&D activities, as for example via strategic alliances with other firms or a wider use of outsourcing. Within this changing environment Odagiri also sees a positive role for the public sector, whether through direct government support for small firm start-ups or through the university sector. An optimistic appraisal is given as to whether recent changes in Japanese business practices (including moves towards greater labour mobility and more flexible inter-firm relations) will have a positive effect upon the rate of scientific innovations both in the specific example of the biotechnology sector and in the more general case of the Japanese economy at large.

The remaining two chapters broach the question of Japan's economic difficulties from the viewpoint of how this has affected Western debate on the Japanese model, from the viewpoint both of the Japanese 'national' economy and of the Japanese corporation.

Chapter 9, by David Coates ('The rise and fall of Japan as a model of "progressive capitalism"') considers Japan in its sometime role as the elected model for a more progressive form of capitalism. Focusing on literature written in the West on Japan in order to address non-Japanese themes, Coates considers how the visible and sustained successes of the post-World War II Japanese economy combined with an increased perception amongst Western commentators of the distinctiveness of Japanese institutions and modes of economic organization to generate a gradually burgeoning literature which identified Japan both as an economic role model and as an alternative to liberal market orthodoxies. In an erudite account, Coates shows how early Western texts on the Japanese growth story in the post-war era moved from accounts written 'within the centre of existing economic orthodoxy', and with explanations rooted in 'ordinary economic causes', to an 
emerging body of writing in the 1970s and 1980s driven by commentators with a broader purview (industrial sociologists, cultural historians, industrial relations specialists and management scholars) concerned to identify factors which rendered Japan qualitatively distinct vis-à-vis the West. Coinciding with the rise of neoliberalism in the US and UK in the 1980s, Japan was cast as a more collectivist alternative and an example of a successful capitalism run along non-neoliberal lines. The chapter explores the subsequent impact on this perception both of the prolonged period of difficulty experienced by the Japan economy in the 1990s and beyond, and of growing criticisms of the 'dark side' of the Japanese miracle.

Chapter 10, by Dan Coffey and Carole Thornley ("Can Japan compete?" reconsidered') considers the issue of changing perceptions about Japan and Japanese corporations as economic challengers in the world economy from the viewpoint of the developing nuances of the international 'competitiveness' debate. Observing that strength in manufacture is frequently adopted as one benchmark of the relative competitiveness of industrialized economies, Coffey and Thornley consider how the economic difficulties which beset Japan in the 1990s are reflected in the treatment accorded its leading manufacturing firms in the best manufacturing practices literature. The phrase 'lean production' is often used today as a summary term by which to encapsulate a series of contributions to best manufacturing practice believed to originate in Japan. Drawing a careful distinction between the interests of private firms and the economic success of nations, and following a critical review of some exemplary contributions to the US competitiveness debate, the chapter considers both the reception given in the US to the idea of lean production, and the subsequent use of this notion in criticisms both of Japan's competitiveness as a nation and of Japan's corporations as strategists. In a provocative twist, Coffey and Thornley argue that, while the evidence to support the idea of lean production as a positively effective and novel set of manufacturing practices has always been nugatory, viewed as a fiction it is a construct which has the potential to shed much light on aspects of the changing course of global economic rivalries.

\section{REFERENCES}

Aoki, M. and R. Dore (eds) (1994), The Japanese Firm: Sources of Competitive Strength, Oxford: Oxford University Press.

Gilpin, R. (2000), The Challenge of Global Capitalism: The World Economy in the 21st Century, Princeton and Oxford: Princeton University Press. 